\title{
PARK CHUNG-HEE DAN KEAJAIBAN EKONOMI KOREA SELATAN
}

\author{
Oleh: Ririn Darini*
}

\begin{abstract}
Abstrak
Korea Selatan merupakan salah satu keajaiban ekonomi Asia. Dalam waktu yang relatif singkat Korea berhasil menjadi negara industri modern sekaligus kekuatan ekonomi yang diperhitungkan oleh dunia. Keberhasilan pembangunannya menjadi model bagi negara-negara lainnya. Keberhasilan ekonomi Korea Selatan tidak terlepas dari peran Park Chung-hee sebagai peletak dasar pembangunan ekonomi Korsel. Park Chung-hee sangat intens dengan program pembangunan. Perhatiannya tercurah untuk melaksanakan program-program dasar untuk pembangunan Korea Tulisan ini mencoba mengkaji kebijakan Park dalam membangun perekonomian Korsel.
\end{abstract}

Kata Kunci: Ekonomi, Korea Selatan, dan Park Chung-hee

\section{A. Pendahuluan}

Indonesia dan Korea merupakan dua negara di Asia yang sama-sama terlepas dari pendudukan Jepang pada tahun 1945. Namun, berbeda dengan Indonesia, Korea Selatan tidak segera mendapatkan kemerdekaannya tetapi negara tersebut justru terpecah menjadi dua bagian dan terlibat dalam perang saudara yang memakan banyak korban jiwa dan menghancurkan perekonomiannya. Meskipun demikian pada saat ini Indonesia jauh tertinggal dari Korea Selatan dalam perekonomian, padahal sumber daya alam Indonesia jauh lebih kaya bila dibandingkan dengan SDA yang ada di Korea Selatan.

Pada tahun 2005 Korea Selatan telah berubah menjadi negara industri yang utama. Di samping merupakan pemimpin dalam akses internet kecepatan tinggi, semikonduktor memori, monitor layar datar, telepon genggam, Korea Selatan juga menduduki peringkat pertama dalam pembuatan kapal, ketiga dalam produksi ban, keempat dalam serat sintetis, kelima dalam otomotif, dan keenam dalam industri baja. Negara ini juga berada pada peringkat ke-12 dalam PDB nominal, tingkat pengangguran rendah, dan pendistribusian pendapatan yang relatif merata. ${ }^{1}$

Pertumbuhan ekonomi Korea sejak kemerdekaan dan setelah kerusakan hebat akibat perang Korea merupakan sebuah contoh keberhasilan

\footnotetext{
${ }^{*}$ Staf pengajar pada Jurusan Pendidikan Sejarah FISE UNY

${ }^{1}$ www.asianinfo.org/asianinfo/korea/economy.htm.
} 
pembangunan ekonomi nasional yang paling luar biasa di dunia. Dari titik terendah yang gelap pada tahun 1953 Republik Korea telah mencapai apa yang disebut sebagai “keajaiban ekonomi di Sungai Han”. Setelah berakhirnya perang Korea tahun 1953, income per kapita hanya mencapai 67 dollar, lebih rendah dari sebelum perang dan merupakan salah satu pendapatan yang terendah di dunia. 40\% struktur telah hancur, 2/3-nya dari sektor industri. Produksi pertanian $27 \%$ lebih rendah dari masa sebelum perang, sehingga tanpa adanya bantuan dari luar banyak orang Korea yang kelaparan. ${ }^{2}$

Sejak Korea memulai pembangunan ekonomi pada tahun 1962, ekonominya telah tumbuh menjadi salah satu yang tercepat di dunia. Transformasi ekonomi di Korea sungguh spektakuler. Dalam waktu kurang dari 30 tahun Korea Selatan maju pesat dari sebuah negara pertanian menjadi negara industri dan perdagangan. Korea saat ini dianggap sebagai model ekonomi untuk disaingi oleh negara-negara lain. Pertumbuhan ekonomi Korea Selatan yang radikal ini dimulai pada masa pemerintahan Jenderal Park Chunghee yang menduduki posisi penguasa melalui kudeta militer tahun 1961. Park Chung-hee kemudian menjalankan pemerintahan di Korea Selatan secara otoriter. Bagaimana kebijakan yang diambil pemerintahan Park sehingga Korea Selatan memiliki pertumbuhan ekonomi yang besar dalam waktu yang relatif singkat? Tulisan ini akan berusaha mengkaji kebijakan Park dalam meletakkan dasar-dasar pembangunan ekonomi Korea.

\section{B. Park Chung Hee}

Keberhasilan ekonomi di Korea Selatan tidak terlepas dari peranan Presiden Park Chung Hee. Ia merupakan peletak dasar pembangunan ekonomi Korea Selatan. Park Chung Hee memulai karier militernya pada dinas ketentaraan kolonial Jepang. Rezim militer di Korea mulai muncul setelah terjadinya kudeta militer oleh Mayor Jenderal Park Chung Hee dibantu rekannya Kolonel Kim Jong Pil pada tanggal 16 Mei 1961, ${ }^{3}$ terhadap pemerintahan sipil Yun Po Son yang juga telah bersama-sama militer menjatuhkan pemerintahan Syngman Rhee yang terkenal korup dan otoriter.

${ }^{2}$ David I. Steinberg, The Republic of Korea: Economic Transformation and Social Change, (Boulder and London: Westview Point, 1989), hlm. 122.

${ }^{3}$ Amerika Serikat cenderung mendiamkan saja jatuhnya Korea Selatan di bawah rezim militer karena sudah banyak dikecewakan oleh pemerintahan Presiden Syngman Rhee yang korup. Banyak bantuan ekonomi AS bagi pembangunan industri yang diselewengkan untuk kegiatan politik. 
Setelah kudeta, sebagai bagian dari konsolidasi kekuatan politiknya, Park mengkonsentrasikan semua kekuatan sosial, politik, dan ekonominya di bawah komandonya. Sebagai mantan militer Presiden Park tertarik untuk menciptakan stabilitas, membangun perekonomian, dan memperkuat pertahanan nasional. Ia tidak mengenal prinsip-prinsip demokrasi atau cara hidup demokrasi. Menurutnya cara demokrasi tidak hanya akan membawa kemajuan ekonomi yang lamban tetapi juga pemisahan sosial dan memperlemah pertahanan nasional. Baginya yang berlaku adalah demokrasi “terbatas”, membatasi kebebasan sipil, kebebasan bicara dan pers. Ia sangat dekat dengan birokratisme dan kepemimpinan militer ala Jepang pada periode Meiji, yang di bawah kepemimpinan militer yang kuat mendorong modernisasi ekonomi dan pembangunan militer melalui ideologi ishin atau revitalisasi. ${ }^{4}$ Park Chung-hee membuat pemerintahannya bertumpu pada kekuatan yang berasal dari militer, birokrat, dan teknokrat. Oleh karena itu rezim Korea Selatan di bawah Park Chung-hee disebut Rezim Otoriter Birokratis. Presiden Park termasuk salah seorang peletak dasar strong military-dominated government di Asia.

Dalam rangka memenuhi tuntutan untuk mengatasi kebutuhan ekonomi yang mendasar dan mendesak, pemerintahan militer di bawah Park Chung-hee mengambil beberapa langkah penting. Pertama, membuka hubungan diplomasi dengan Jepang untuk mengundang arus PMA dan bantuan ekonomi dari negara tersebut. Kedua, mengambil sikap mengalah terhadap tekanan-tekanan dari AS (terutama untuk mendapatkan dukungan politik dan pengakuannya) serta menerima anjuran dari kelompok teknokrat untuk menggalakkan usaha-usaha ekspor, terutama ekspor hasil-hasil industri manufaktur. ${ }^{5}$

Kebijakan pembangunanisme menunjukkan dominasi negara (penguasa) sebagai pihak yang paling menentukan hubungan industrial. Di pihak lain kekuatan demokrasi yang mulai muncul semakin memperbesar tekanan rakyat terhadap kebijakan Park Chung-hee. Untuk menjaga stabilitas programnya Park Chung-hee memilih garis politik represif. Park Chung-hee membungkam seluruh potensi oposisi. Dengan demikian Park Chung-hee merasa perlu untuk mengadakan suatu perubahan mendasar untuk menjatuhkan

${ }^{4}$ Andrew C. Nahm, Introduction To Korean History and Culture, (Seoul: Hollym International, 1993), hlm. 196.

${ }^{5}$ Hero Utomo Kuntjoro-Jakti, Ekonomi Politik Internasional di Asia Pasifik, (Jakarta: Erlangga, 1995), hlm. 114. 
lawan-lawan politiknya. Maka pada tanggal 6 Desember 1971 dengan dalih mengamankan negara dari demonstrasi-demonstrasi, presiden dengan dukungan militer mengumumkan negara dalam keadaan darurat perang, membubarkan Majelis Nasional, menutup semua universitas yang menjadi basis demonstrasi, melarang semua kegiatan politik, dan pada bulan Oktober 1972 mengeluarkan dekrit presiden yang kemudian dikenal sebagai Konstitusi Yushin. $^{6}$

\section{Economic Planning Board (EPB)}

Peran negara dalam mendorong pertumbuhan ekonomi di Korea adalah dengan mengarahkan dan menciptakan kondisi-kondisi yang memungkinkan untuk investasi modal, produksi, dan juga ekspor. Salah satunya adalah dengan membentuk Badan Perencanaan Ekonomi (EPB) pada bulan Juni 1961. EPB yang diketuai Wakil Perdana Menteri bertanggung jawab terhadap Repelita (Rencana Pembangunan Lima Tahun). Program Repelita disusun dalam empat tahap dimulai pada tahun 1962. Tahap pertama dan kedua diarahkan untuk pembangunan industri. Tahap ketiga (1972-1976) untuk menciptakan keseimbangan antara pembangunan industri dan pertanian, dan tahap keempat (1977-1981) adalah pembangunan ekonomi yang mandiri dan pemerataan hasil pembangunan.

Perencanaan, penentuan anggaran dan pelaksanaan rencana-rencana yang dilakukan oleh Kementrian-kementrian Perdagangan dan Industri, Keuangan, Bangunan, Transportasi, Komunikasi, serta Pertanian dan Perikanan berada di bawah pengawasan EPB. EPB mencanangkan target-target untuk semua variabel ekonomi terpenting termasuk investasi, konsumsi, tabungan, tingkatan-tingkatan output, impor dan ekspor, serta alokasi-alokasi terinci oleh sektor-sektor industri. EPB bersama dengan kementrian-kementrian itu mempunyai wewenang untuk mengubah pajak, tarif, subsidi, tarif keperluankeperluan umum, mengontrol harga barang-barang tertentu, dan juga mengubah lisensi-lisensi impor, lisensi-lisensi investasi, penggunaan devisa,

${ }^{6}$ Konstitusi ini dimaksudkan untuk mengukuhkan kediktatoran Park Chunghee. Melalui sistem ini presiden dipilih secara tidak langsung oleh Dewan Unifikasi Nasional yang dibentuk secara manipulatif dan khusus bertugas untuk memilih presiden. Presiden juga diberi wewenang untuk menunjuk 1/3 anggota DPR yang memungkinkan presiden untuk mengontrol lembaga legislatif secara langsung. Otoritarianisme Park Chung-hee mendapat dukungan dari kalangan birokrasi, militer, dan polisi. 
dan lisensi-lisensi pendirian usaha baru tanpa membutuhkan persetujuan Majelis Nasional. ${ }^{7}$

EPB mempunyai kekuasaan yang sangat besar termasuk menguasai bank-bank komersial. Negara merupakan pemegang saham terbesar sehingga sangat berkuasa dalam menentukan kebijakan-kebijakan perbankan. EPB mempunyai kekuasaan untuk memelihara sekaligus menekan kaum borjuis nasional Korea Selatan. EPB juga mengorganisir informasi-informasi terinci mengenai pasar internasional dan perubahan-perubahannya dari laporanlaporan yang diserahkan perusaahaan ekpor. ${ }^{8}$

\section{Kebijakan Export-Oriented Industrialization (EOI)}

Sejarah industri di Korea sudah berlangsung sejak masa penjajahan Jepang di Korea. Banyak industri dibangun untuk menopang ekonomi Jepang. Korea Selatan diuntungkan dengan warisan Jepang berupa sarana-sarana infrastruktur seperti jalan raya, rel kereta api, listrik, saluran irigasi, tenaga terdidik dalam industri dan manajemen, dan sejumlah pabrik yang mampu menyediakan suatu basis industri ringan meskipun dalam jumlah dan kekuatan terbatas. Korea Selatan sudah memiliki basis sosial dan ekonomi yang cukup kuat dan memadai untuk memulai kembali program-program industrialisasi subtitusi impornya.

Di bawah tekanan kuat AS, pihak Jepang terpaksa menjual pabrikpabriknya dengan harga yang relatif murah pada para pengusaha Korea. Pada masa pemerintahan Presiden Syngman Rhee proses industrialisasi yang berbasis pada industri substitusi impor mulai bangkit. Pelan-pelan industri tradisional Korea Selatan yang sudah hidup sejak jaman kolonial seperti industri tekstil, pengilangan tepung dan pabrik gula ikut tumbuh. Pada masa ini para chaebol ${ }^{9}$ mulai memperoleh modal. Namun pemerintahan Rhee yang korup memporakporandakan ekonomi Korea Selatan.

\footnotetext{
${ }^{7}$ Alexander Irwan, "Kenaikan Upah Riil pada Sektor Pengolahan di Korea Selatan”, Prisma, No. 8, Th. 1989, hlm. 46.

${ }^{8}$ Ibid., hlm. 46-47.

${ }^{9}$ Salah satu fenomena istimewa Korea yang dibangun oleh pemerintah adalah chaebol. Chaebol adalah konglomerat-konglomerat raksasa, dikuasai oleh sistem keluarga yang sangat sentralistik yang mendominasi perekonomian. Mereka memiliki koneksi dengan pusat-pusat kekuasaan, dan merekalah yang kelak menjadi cikal-bakal sejumlah konglomerat besar yang menjadi tulang punggung perekonomian Korea
} 
Pada masa Park pemerintah berperan aktif mengarahkan sektor swasta khususnya chaebol untuk mewujudkan agenda pembangunan yang disusun oleh pemerintah berupa pengembangan industri manufaktur seperti elektronik, otomobil, dan semikonduktor. ${ }^{10}$ Sebagian produk industri yang didukung pemerintah diarahkan untuk pasaran ekspor karena tidak memiliki pasaran dalam negeri. Pemerintah memberikan berbagai kemudahan dalam hal perkreditan bagi para eksportir. Pemerintah juga mengatur alokasi kredit yang disesuaikan dengan pertumbuhan sektor-sektor industri dan ekonomi yang pada umumnya lebih diprioritaskan. Pemerintah Korea Selatan juga mendapatkan pinjaman luar negeri baik dari Jepang maupun Amerika Serikat.

Keberhasilan ekspor Korea Selatan yang pertama terjadi pada ekspor produk industri ringan seperti tekstil dan pakaian jadi, komponen elektronik, plywood, wig, serta barang-barang perantara (produk-produk kimia, minyak bumi, kertas, dan baja) yang berlangsung dalam kurun waktu antara tahun 1964-1974. ${ }^{11}$ Keberhasilan Korea Selatan pada periode tersebut sangat ditunjang oleh perkembangan ekonomi dunia yang tengah mengalami lonjakan pertumbuhan industri yang luar biasa, sehingga Korea Selatan tidak menemui kesulitan yang berarti untuk memasarkan produk-produknya, terlebih Korsel mendapatkan referensi untuk masuk ke pasar domestik Amerika.

\section{E. Kebijakan Heavy Chemical Industry(HCI)}

Korea Selatan memasuki tahap pembangunan industri yang disebut sebagai pendalaman (deepening proces) pada paruh kedua dasawarsa 1970-an. Pada masa ini terjadi perubahan orientasi industri yaitu dari industri ringan ke industri berat. Pada tahun 1973 pemerintah memberikan prioritas pada perkembangan industri berat dan kimia, misalnya pembuatan kapal, industri permesinan, baja, mobil, dan petro kimia. Pertama karena terdapatnya keterbatasan dalam mengekspor hasil industri ringan yang sangat tergantung pada tenaga kerja murah yang semakin sulit didapat. Kedua, terjadi perubahan

Selatan. Beberapa chaebol besar sampai saat ini adalah Hyundai, Samsung, Lucky Goldstar, Daewoo, Sunkyong, dan Ssangyong.

${ }^{10}$ Dwitri Waluyo, "Chaebol Berpayung”, http://www.hamline.edu.apakabar/basisdata/1996/05/10/0024.html.

${ }^{11}$ Hero Untoro, loc.cit. 
dalam struktur impor. Pesatnya perkembangan dalam pemakaian bahan penengah impor untuk jadi barang ekspor mempengaruhi balance of payment. ${ }^{12}$

Rencana pembangunan industri berat dan kimia merupakan usaha Korea Selatan untuk membuat kekuatan industrinya lebih mandiri. Rencana besar yang didukung oleh presiden, Ministry of International Trade and Industry (MITI), dan sejumlah perusahaan besar nasional (chaebol) dilaksanakan tanpa menghiraukan tantangan kelompok teknokrat. Rencana ini justru mendapatkan dukungan dari militer dan hal ini erat berhubungan dengan sumbangannya untuk industri militer kelak. ${ }^{13}$

Para chaebol mendapat dana pinjaman tanpa bunga untuk mendirikan pabrik untuk kegiatan ekspor. Misalnya Hyundai ditugasi untuk membangun sektor otomotif. Daewoo yang merupakan spesialis di bidang tekstil diperintahkan untuk menangani pembuatan perkakas mesin, membuat kapal dan mobil. Park memaksakan pembangunan sejumlah industri dasar di antaranya industri baja, salah satunya adalah Pohang Steel Company (POSCO). ${ }^{14}$

Sayangnya kebijakan ini terhambat oleh sejumlah kesulitan eksternal yaitu krisis minyak dan resesi perekonomian dunia. Di dalam negeri terjadi lonjakan inflasi dan perkembangan ekspor Korea Selatan juga mulai terancam. Namun Korea Selatan masih beruntung sebab sektor-sektor konstruksinya memperoleh peluang bisnis yang sangat besar terutama dengan berlangsungnya pembangunan ekonomi di negara-negara Timur Tengah yang kaya minyak. Kebanyakan industri di Korea Selatan memperoleh manfaat yang sangat besar dari arus PMA dan proses alih teknologi dari Jepang yang mulai digalakkan kembali sejak pembukaan kembali hubungan diplomasi antara kedua negara.

\section{F. Gerakan Saemaul Undong}

Gerakan saemaul merupakan gerakan yang dimaksudkan untuk mengembangkan dan memodernisasikan daerah pedesaan. Tujuannya adalah untuk membangkitkan semangat kemerdekaan (indipendence), kemandirian (self-help) untuk mewujudkan gerakan desa baru (New Village Movement), dan

${ }^{12}$ Yo Hanjohng, "Sejarah Ringkas Ekonomi Korea Periode Rekonstruksi (1953-1961)”, Korea Jurnal, Vol. 1, No. 1, Maret 1989, hlm. 22.

${ }^{13}$ Hero Utomo, op.cit., hlm. 71.

${ }^{14}$ Saat ini POSCO merupakan industri baja terbesar kedua di dunia setelah Nippon Steel dari Jepang. 
kerja sama atau sifat gotong royong (Mutual Cooperation) dalam rangka meningkatkan taraf hidup masyarakat setempat.

Konsep ini diperkenalkan pada tahun 1971 ketika Korea Selatan menghadapi permasalahan disparitas pedesaan-perkotaan akibat prioritas pembangunan yang selalu menekankan industrialisasi berorientasi ekspor. Keberhasilan pembangunan ekonomi Korea Selatan ternyata menimbulkan masalah-masalah sosial. Pada saat itu tingkat pertumbuhan sektor pertanian tertinggal jauh dari sektor industrial. Ketika terjadi pertumbuhan ekonomi, gap antara pendapatan rumah tangga petani dengan pendapatan masyarakat urban semakin besar. Hal ini mengakibatkan eksodus pemuda desa ke wilayah urban, meninggalkan desanya tanpa kemampuan yang memadai dan menciptakan tekanan penduduk di wilayah-wilayah urban.

Untuk mengurangi kesenjangan ekonomi antara desa dengan kota, Presiden Park mencanangkan Gerakan Masyarakat Baru dengan tujuannya sebagai pencerahan rakyat pedesaan melalui 'pendidikan masyarakat baru' untuk mengubah bentuk pandangan dan tingkah laku ikatan tradisional dan jeratan kemiskinan masyarakat desa, membantu mengembangkan kerajinan dan penghematan, semangat untuk kerja sama dan menolong diri sendiri, dan memodernisasi masyarakat pedesaan.

Selain mencegah kecenderungan tak seimbang antara industriperkotaan dengan pertanian-pedesaan, konsep ini berupaya memperbesar saluran pembangunan sektor ekonomi pertanian-pedesaan. Gerakan dimulai dengan menginventarisasi aset lokal yang jarang dimanfaatkan dan diolah menjadi sesuatu yang dapat memperbaiki standar hidup setempat dan memperbesar keuntungan yang diperoleh warga. Esensi lain Saemaul Undong adalah wujud pembangunan dari bawah berdasarkan inisiatif dan partisipasi lokal. Proyek ini diwujudkan melalui pembentukan koperasi warga setempat yang berpedoman pada inisiatif lokal, pemanfaatan tenaga kerja serta material dan ketrampilan mereka. ${ }^{15}$

Saemaul undong dioperasikan melalui tiga tahapan. ${ }^{16}$ Pada tahap awal dilakukan berbagai perbaikan lingkungan hidup pedesaan terutama yang menyangkut fasilitas fisik. Tahap selanjutnya adalah memperbaiki infrastruktur dasar, dan tahap terakhir adalah memperluas kesempatan kerja pertanian dan

15 Hilmy Mochtar, "Strategi Pembangunan Kawasan Periferal: Pengalaman Korea Selatan dan Filipina”, Prisma No. 8, Agustus 1996.

${ }^{16}$ Ibid., hlm. 59. 
non-pertanian di samping menggarap aktivitas lain yang dapat meningkatan pendapatan dan kesejahteraan warga setempat.

Pada tahun 1973 pemerintah membuat Village Cooperative Scheme (VCS) untuk memperluas cakupan wilayah proyek saemaul. Sebuah desa dapat membentuk kerja sama atau sebuah unit produksi bersama dengan desa tetangga. Proyek-proyek komunitas baru menghasilkan modernisasi perumahan masyarakat desa, pembangunan jalan-jalan dan saluran air, pembangunan sistem sanitas, dan memberikan pengetahuan ilmu sain dan teknologi bagi masyarakat desa, industri di pedesaan, dan fasilitas pemasaran. Gerakan komunitas baru memberikan hasil-hasil yang menguntungkan bagi wilayahwilayah pedesaan, juga wilayah-wilayah urban. Gerakan nasional ini merupakan cara untuk memelihara semangat kerja sama dan persatuan.

Sejak diperkenalkannya Saemaul Undong, pada tahun 1978 terdapat 706 pabrik yang dibangun di kawasan pedesaan yang hampir seluruhnya mendapat insentif pemerintah berupa subsidi. Investasi pemerintah hanya sebagai pelengkap dalam kaitannya dengan organisasi dan mobilisasi sumber. ${ }^{17}$ Tahun 1970-1979 pendapatan petani mengalami peningkatan sebesar 9,5\% per tahun. Gerakan Saemaul mampu menyerap tenaga kerja dan meningkatkan investasi di daerah pedesaan. Pada tahun 1960-an laju investasi sebesar 10\%, setelah diterapkannya gerakan Saemaul meningkat menjadi $20 \%{ }^{18}$

\section{G. Kesimpulan}

Kemajuan ekonomi Korea Selatan yang berjalan dengan sangat mengesankan sampai saat ini telah dimulai dari kebijakan ekonomi yang dilakukan oleh Park Chung-hee. Korea Selatan mampu membangun kekuatan industri yang begitu dahsyat meskipun tidak didukung oleh sumber daya alam yang memadai. Hal ini menunjukkan bahwa kesuksesan pembangunan ekonomi Korea terletak pada kemampuan manusianya, terutama pada pemimpinnya berkaitan dengan strategi kebijakan yang dijalankannya. Pemerintah menyadari pentingnya industri dasar yang akan menjadi katalis bagi berkembangnya industri hilir lainnya.

${ }^{17}$ Ibid., hlm. 60.

${ }^{18}$ Mulyadi Sumarto, "Saemaul Undong: Ideologi, Pendekatan dan Kontribusinya”, Makalah Lokakarya Tentang Korea III (Yogyakarta: Pusat Studi Korea dan the Foundation of Korean, 2006), hlm. 215. 
Keajaiban ekonomi Korea Selatan yang telah dicapai sampai saat ini tentu bukan semata-mata pada faktor pemerintahnya saja melainkan juga dukungan masyarakat Korsel itu sendiri. Budaya kerja dan etos kerja yang tinggi serta kecintaan terhadap produk-produk dalam negeri menjadikan produk-produk yang dihasilkan Korea dikonsumsi oleh pasar dalam negeri dan luar negeri. Dengan melihat pengalaman yang ada Indonesia dapat belajar dari Korea.

\section{Daftar Pustaka}

Alexander Irwan, "Kenaikan Upah Riil pada Sektor Pengolahan di Korea Selatan”, Prisma, No. 8, Th. 1989.

Dwitri Waluyo, “Chaebol Berpayung”, http://www.hamline.edu.apakabar/basisdata/1996/05/10/0024.html.

Hero Utomo Kuntjoro-Jakti, Ekonomi Politik Internasional di Asia Pasifik, Jakarta: Erlangga, 1995.

Hilmy Mochtar, "Strategi Pembangunan Kawasan Periferal: Pengalaman Korea Selatan dan Filipina”, Prisma, No. 8, Agustus 1996.

Mulyadi Sumarto, "Saemaul Undong: Ideologi, Pendekatan dan Kontribusinya”, Makalah Lokakarya Tentang Korea III (Yogyakarta: Pusat Studi Korea dan the Foundation of Korean, 2006.

Nahm, Andrew C., Introduction To Korean History and Culture, Seoul: Hollym International, 1993.

Steinberg, David I., The Republic of Korea: Economic Transformation and Social Change, Boulder and London: Westview Point, 1989.

www.asianinfo.org/asianinfo/korea/economy.htm

Yo Hanjohng, "Sejarah Ringkas Ekonomi Korea Periode Rekonstruksi (19531961)”, Korea Jurnal, Vol. 1, No. 1, Maret 1989. 